\title{
SWOT Study on the Development of Chinese Adult Education
}

\author{
Xiaoping Wang \\ Yanshan University Liren College \\ Hebei Province, China \\ wxpcw2005@126.com
}

\begin{abstract}
Adult education in China has been following higher education mode for years without reflecting the characteristics as continuing education since the source of students are mainly from the rest of the admission of higher education. With the expanding college enrollment, the quantity and quality of the students of adult education have been decreasing which has affected school running and caused a shrinking school size. With an eye on the importance of adult education of the present stage, this paper analyzed the strengths, weaknesses, opportunities and threats of the adult education adopting SWOT strategy and further discussed the strategies and implementations of the development of adult education.
\end{abstract}

\section{Keywords-adult education; development; SWOT; strategy}

Adult education has come to a downturn since the expansion of China's universities enrolling in 1999. Educators keep struggling with how to position adult education in the past decades, only fill the gaps for general education? where is the way out of this downturn? Here the author try to search and analyze the development of China's adult education using SWOT methodology and may get some new inspiration.

\section{VIEW AdULT EdUCATION RESEARCH FROM SWOT PERSPECTIVE}

SWOT is also known as Situational Analysis method or Walter Analysis method, it is first proposed by Learned et al. in 1965. It is an approach which can analyze and research the real situation of an enterprise objectively and has been accepted all over the world, this method has also been popularized to selfdiagnosis and strategic decision of various organization behaviors. In a sense, the innovation and development of adult education is a typical organization behavior, so SWOT is a real new perspective for adult research.

SWOT stands for Strength, Weakness, Opportunity and Threat, they are four key factors in strategic analysis. For adult education, separate and analyze of those four key factors can derive "Two Mainlines", "One Matrix" and "Four Strategies"[1].

SWOT analysis can be divided into two mainlines which are "S-W" and "O-T". The first one is "S-W" which is mainly used to analyze the internal conditions of adult education development, it takes the relatively stable internal environment in adult education development as its target and it is primarily to recognize advantages and find disadvantages. $\mathrm{S}$ and $\mathrm{W}$ are positive and negative elements during adult education development itself. Not only the history and actuality, but also long-term future development should be considered when surveying these elements. The second mainline, "O-T" analysis is mainly used to analyze the external conditions of adult education development that is taking the changing external environment as its target to identify opportunities and provide insight into threats. Through analyzing various external environment of adult education including opportunities and threats, we can understand how good or bad that external environment influence adult education development directly or indirectly. Then determine the internal and external strategy of adult education development from analyzing these two mainlines and on this basis form a overall strategy of adult education development.

A SWOT Matrix is built with permutation of all research result of various factors according to their importance and urgency. The prerequisite of adult education innovation is to investigate problems in current adult education development comprehensively and systematically, to do this, we should make comprehensive analysis on the internal and external environment factors that influence adult education development and make the important and urgent factors prior to the one which is not important or urgent. Among them, important factors can also be divided into what is urgent and what can wait, similarly, urgent factors can also be divided into primary and secondary. Together with previous permutation, a matrix of basic situation is formed. From this matrix, it is clear which factors are favorable to adult education development and which are bad and have to be avoided, and then the problem can be discovered and solved. Especially, correlating those factors together and analyze can provide theatrical and practical bases to scientific decision-making and will help leaders and managers to make an overall plan, it can also provide best development strategy for the innovation and development of China's adult education.

Situation analysis method is not the goal, the goal is to research and determine the strategy of adult education development, devote major efforts to developing adult education and realize coordinate development between adult education and other forms of education. Based on the above analysis, we can make four development strategies which consider of both inside and outside: SO, ST, WO and WT. SO strategy means rely on internal advantages, take external opportunities and take full advantages of core competitiveness of adult education. ST strategy means utilize internal advantages and restraint external threats and find a way of characteristic development to adult education. WO strategy is 
to overcome internal weakness and utilize external opportunities, implement dislocation development of adult education. WT strategy means change internal weakness and fends against external threats, explore a road of normalization and legislation for adult education.

\section{SWOT ANALYSIS TO THE CURRENT SitUATION OF ADULT EDUCATION}

To realize the development and innovation of adult education by reference to the thinking method using four factors and two mainlines, the first thing to do is to survey the internal environment of adult education comprehensively and systematically, identify its internal strengths and weaknesses, and on this basis, research the influence of these factors to adult education. In the second place, base on analyzing the internal environment of adult education, it is also necessary to inspect the external environment of adult education, recognize and discover the opportunities and challenges in external environment, thus build a good environment for adult education development, form a long-term benign and interactive mechanism, promote the innovation and development of adult education.

\section{A. Advantage Analysis}

Advantage is core competence to adult education itself, so realizing and utilizing advantages sufficiently is an important entry point for adult education to gain sustainable competitiveness. There are four major advantages of adult education:

1) Pertinence of Course Content. Comparing with other forms of education, the content of adult education is more close to the technological advances, social demands and talent training, it is even more easy to find out the joint point of economic development, social progress and human development.

2) Continuity of Education Process. Adult education is a bond between pre-service education and permanent education, it is a bridge from disposable educational to continuous education, it can also consolidate, improve and update the preservice knowledge during regression and continue.

3) Flexibility of Education Forms. Adult education has passed through beginning, development, adjustment, maturity and redevelopment and has figured out various education forms such as academic education, non-academic education, self-taught examination and pre-employment training, this makes continuing education, return education and life-long education possible and feasible.

4) Diversity of Education Means. The diversification of education demand and flexibility of education form makes the means of adult education become multifarious. The various means of education which bases on modern audiovisual and network communication technology has become the realistic tendency of adult education.

\section{B. Weakness Analysis}

Weakness is a limiting factor for adult education, the analysis of limiting factors can help us adopt measures, wipe out blind spots and extend reach. In recent years, along with the rapid expansion of adult education, some unstable disadvantage factors come up gradually, mainly showing as:

1) Backward Educational Concept. Currently, some relatively independent and wholesome adult education college is hard to bring their advantages, they lack of both macrograsp to the whole education and microexamination of adult education's advantages. Current adult education mode is still continue with the so-called "formal education" which has been influenced by general education pattern such as academic education, subject education and theoretical education, so it is not innovative.

2) Weak Brand Awareness. For a long time, adult education depends too much on regular higher education during its development and lack of own characteristics in pedagogy of teaching materials, it even simply believe that the more similar with regular college, the higher schooling level they are. The goal of adult education is to cultivate technology applied talents, without this brand, adult education will has no value itself.

3) Poor Teaching Staff. It is a fact that the teaching staff of adult college is not performing to the required level on education background, structure of knowledge and ability. Most teachers are good at theory teaching but weak in practical ability and know little about specialized knowledge, they lack of original idea and judgment of their own majors, this is far from the "Double Type" teacher which has been raised by our country.

\section{Opportunity Analysis}

It is a major objective of external environment analysis to recognize opportunities, it is a main acting point of adult education to seize opportunities duly. Currently, the main opportunity of adult education in our country includes:

1) The advent of digitization of information provides a broad space for adult education. Webucation has characteristics such as openness, flexibility, interactivity, high efficiency and large information capacity. This can provide adult education with a wider living and developing space.

2) The change of industry structure requires more and more front line technical labourers. The developing trend of vocational education indicates that the front line technical talents are the most demanded people during the economics change from labor intensive to technology intensive in our country. But to the front line technical labourers, general education is disadvantaged and adult education should be advantaged.

3) Adult education is the first place to be affected when realizing life-long education. Insiders believed that in the near future, lifelong learning will change from a kind of task to conscious action of self-improvement and development, lifelong education will also become a social group behaviour from individual behavior. Both those two type of transformation depend on the innovation and development of adult education.

4) The construction of new socialist countryside has opened a broad road which strives to develop country adult education. Practice indicates that adult education has made significant historic contributions to country eliminate illiteracy, 
agricultural technology training, country adult diploma education, citizenship education and socioculture education. Currently, China is in the historical period of constructing a well-off society and new socialist countryside, only develop rural adult education positively can we provide intellectual support and talent guarantee to rural construction and accelerate the material civilization and spiritual civilization construction.

\section{Threat Analysis}

Threat analysis is a recognition process of factors against adult education in external environment. It can bring up general plans and measures specifically. it is undeniable that, together with the growth of advantages of adult education, some disadvantages also come up quietly.

1) Intense Competition within Industry. Along with the higher education development from "elitism" to "popular", some new private colleges and private schools rise rapidly, combined with the potential compention from joining the WTO, all of these will has great impact to survival and development of adult education. Any slight carelessness will result in the risk of elimination.

2) Hard to change with historical tradition of urbanization and real pattern. Although new development approaches have been brought to adult education by the construction of new socialist countryside, but the rurual adult primary vocational education in our country is slow and the secondary vocational education is immature, adult higher vocational education mainly focuses in cities, so it is difficult convert to agriculture quickly and may not meet the strategic target of constructing socialism new countryside in the country's latest five-year plan.

3) Management mechanism has not been straighten out. During the development of adult education and from macroscopic aspect, the government is weak in macromanagement of plan, coordinate, supervise and assessment, a benign management mechanism of adult education has not yet formed. On the micro level, talent introduction mechanism, school management mechanism, student management mechanism, danger emergency mechanism and teaching staff construction are still vulnerable spots for the current adult education management mechanism.

4) Insufficient social attention. Some wrong understanding such as paying too much attention to general education, despise or disdain adult education is still ubiquitous in current society, and this makes adult education schools face with problems like lacking of educational fund, shabby teaching facilities, hard to scale up and lacking of student source.

\section{SWOT STRATEGY OF CHINA ADULT EDUCATION DEVELOPMENT}

The innovation and development of adult education is a systems engineering, it refers to many aspects such as educational concept, educational objectives, management system and institutional construction. Through analysis, we have inspected the internal and external environment of adult education comprehensively and systematically and the innovative strategy matrix has become clear. Then how to take opportunities, exploit the advantages, cope with the challenges and make up for the deficiency? We should start from the current adult education reality, orientate scientifically, adjust the pattern, seize opportunities, innovate approaches, standardize management and carry out work innovatively. According to the SWOT approach, it requires four strategies to implement a sustainable adult education.

\section{A. Put SO Strategy Into Effect: Orientate scientifically, adjust the pattern and keep a foothold on regular development}

"Rapid development of science and technology, the active demand of talents from economic construction and the worldwide competition of comprehensive national power is the basic impetus to continuing education and its development[2]. Most adult colleges in our country rely on general college and lack of independence. They follow general college blindly on cultivate principle, educational patterns and teaching methods and lost their own orientation, thus they are treated as accessories of other educations. Along with the in-depth development of information technology, new techniques and knowledges are constantly emerging, people also change their work frequently, so update knowledge and improve skills has become a compulsory course. Education and life-long study will become the represent the general trend. Back to carring out education research in a deep-going way, people find that return education has not only theoretical research value, but also has realistic maneuverability. Return education is an education pattern which needs transformation between education and labor, it has openness of education system, interactivity of educational practice, long-life continuity, diversity of education level and richness of content. Against the particularity of current adult education and considering the characteristics of return education, return education is an efficient path for the innovation of adult education. Through "return" and bilateral interaction between "labor" and "study", educates can improve the quality of themselves, update their knowledge and strengthen their innovation ability. On the other hand, adult education should aims at the trend of life long education to adjust the layout structure of adult primary education, secondary education and higher education to realize regular development.

\section{B. Put ST Strategy Into Effect: seize opportunities, restrict disadvantages with advantages and seek characteristic development}

The existing normalization trends and general education mode has made our country's adult education lost its characteristics and this has caused great waste and serious imbalance of education resources. "Many education institutions have paid little attention to the adult education management, or even emphasis only on diploma but educating people, and thus makes the quality of general adult education fall"[3].Therefore, adult education should also seize opportunities actively to seek characteristic development.

1) Adult education should has a foothold on the local area, mining advantages and form self-brand. Adult education can not live without local reality, we should lucubrate the joint point between provincial economy and academies, overcome our own shortcomings and defects, base on the social development and provincial reality to adjust major-setup and 
personnel training mode duly and fix on developing target which is suitable to ourself.

2) Adult education should takes everything into consideration when put characteristic development into the domestic and international education competition environment. Adult education in our country should actively absorb advanced foreign education concept and means, consistently improve the quality of talents and catch up with top international adult education schools in scientific research and talent cultivation. Vigorously carry out innovation research with international advanced level to form self school-running characteristics and advantages.

3) From practical experience at home and abroad, the characteristic of adult education lies not in formal and academic education, but in professional technical education and non-formal education. We should take full advantage of the available resources from society and schools, increase the input on advantages gradually and continuously and try to optimize and upgrade the school competitiveness in the shortest time.

\section{Carry Out WO Strategy: Find innovated ways, expand spaces and implement dislocation development to adult education}

How does adult education face the intense competition of education resource? The competition-exclusion phenomenon in nature has provided us some clue on "dislocation development".

1) Spatial Mismatch: rural education. Recently, the key to accomplish socialism new rural reconstruction successfully is how to take positive and effective ways to solve the education problem of 900 million peasants. In the increasingly fierce educational competition and the huge rurual latent market, adult education should put attention to country, this can not only avoid cutthroat competition with other education types or forms, but also have a large source of students.

2) Time Mismatch: short-cycle education.Although medium and long term education has its own advantages, but learn from practice, short-term concentrate education suits the fast-paced society and the mental profile and learning characteristics of young people.

3) Approach Mismatch: modern education. "Network education in colleges are still in the ascendant and is becoming a new increase point of education"[4]. Through modern communication facilities, adult education can set up their subsidiaries to cover all cities, education platforms in both country and remote mountainous areas, this can not only solve the problem of teacher shortage and satisfy further study of different level students, but also form a big adult education network in provinces, regions, cities, counties and villages to share recourses and complement advantages.

\section{Take WT Strategy: Perfect laws and regulations and explore legal development}

The perfection of country law and policy is the fundamental guarantee to education development. The development of adult education in developed countries benefits much from their legislative guarantee. "Along with the trend of economic globalization and deepening of China's reform and opening up, it bring continuing education unprecedented impact at the same time it bring us development opportunities"[5]. All basic principles, basic systems and administrative systems abroad about adult education is stipulated, controlled, adjusted and supervised in the form of clause. Many countries have their own laws on adult education and establish a series complete set of laws such as Law of Vocational Training Legislation of Cooperation in US, Law of Employment and Training in England, Law of Perfecting the Revitalization of Lifelong Learning Policy System in Japan and Law of Vocational and Technical Education in France. Although we have attached great importance to education legislation, but it still has a lot of shortages comparing with foreign adult education legislation. As the adult education development appears diversification, variety of running schools and hierarchy of type, it will definitely bring greater hardship to adult education. So we should take a road legalized to keep the strategic position of adult education, give play to its functions, solve problems that appear during adult education development and create a rosy prospect of adult education.

\section{REFERENCES}

[1] Xiao Na, Application of SWOT analysis in the administration of the enterprise, Group Economy, vol.58,pp.1-2,2004.

[2] Hu Tianyou, Continuing education in universities: Opportunity, Challenge and Strategy, Vocational and Technical Education,vol. 61,pp.7,2013.

[3] Yan Zhaohui, The development strategy and management innovation research in adult education in common colleges and universities, Academic Exploration,vol.58,pp.1-2,2004.

[4] Lai $\mathrm{Li}$, College degree to continue education development space analysis, Contemporary Continuing Education, vol. 17, pp. 2, 2013.

[5] Wang Sunyu,Tian Huijun, Institutions of higher learning to continue education development strategy analysis and countermeasure research, Adult Education, vol. 28, pp.6, 2013. 